\title{
Collective Bargaining and Professional Development of Academic Librarians
}

\begin{abstract}
A survey of academic librarians employed in public colleges and universities was completed in December 1979. * The survey was conducted among a group of academic librarians included in collective bargaining units and a group of academic librarians not included in a collective bargaining unit. The two-fold purpose of the study was (1) to determine to what extent the librarians were involved in a selected group of professional development activities; and (2) to determine if the extent of involvement varied significantly between the two groups of librarians. The survey revealed no significant difference between the two groups of librarians in their involvement in the selected professional development activities.
\end{abstract}

\section{INTRODUCTION}

The interest of librarians in collective bargaining is the subject of numerous studies. Among the approaches to this topic are: historical accounts of the development of unions in libraries; ${ }^{1}$ examinations of the attitudes and opinions of librarians and others toward aspects of collective bargaining; ${ }^{2}$ the development of a framework to study why certain libraries in a given environment will unionize while another library in that environment does not; ${ }^{3}$ and a study of the treatment of academic librarians in collective bargaining agreements. ${ }^{4}$ In addition, the literature includes arguments for and against collective bargaining in libraries. ${ }^{5}$

As the issue of collective bargaining continues to face librarians, more studies are needed to determine its implication for all aspects of librarianship. For instance, we must know more about the impact of collective bargaining on the professional development of librarians. A question that must be addressed is whether the presence of collective bargaining has a harmful effect on the professional development of academic librarians. This question assumes that there are cer-

"Based on the author's unpublished Ph.D. thesis (1980).

William Caynon is assistant professor, School of Library Science, Kent State University, Kent, Ohio. tain activities that may be associated with or that are indicative of the professional development of librarians. A better understanding of the relationship between these activities and collective bargaining is needed. This type of information, coupled with other types of information related to collective bargaining among librarians, should improve the ability of librarians to make more informed value judgments concerning the implications of collective bargaining for librarianship.

The study was influenced by three assumptions: (1) The professional development of academic librarians is measurable using a select group of activities that are quantifiable; (2) faculty collective bargaining is a phenomenon of public higher education and only a comparatively small percentage of private higher education institutions are involved in collective bargaining; ${ }^{6}(3)$ librarians are usually included in college and university faculty collective bargaining units.

Professional development activities have been defined as activities and efforts on the part of librarians to upgrade their knowledge, abilities, competencies, and understanding of their field of work or specialization so that they may become more effective professionals and so that they are able to assume responsibilities of greater scope and accountability. ${ }^{7}$ This definition was a basis for selecting the following activities, which may be associated with or indicative of the profes- 
sional development of academic librarians: (1) membership in professional library associations; (2) attendance at library association meetings; (3) membership in nonlibrary professional associations; (4) attendance at nonlibrary professional association meetings; (5) reading library journals; $(6)$ reading nonlibrary professional journals; (7) attendance at workshops, short courses, or seminars (both library and nonlibrary); (8) visits to observe other libraries; (9) reading of professional books; (10) publishing of journal articles; (11) publishing papers in proceedings; (12) publishing articles or chapters in books; (13) publishing or editing books; and (14) editing journals.

No attempt was made to include all of the activities that may be associated with the professional development of academic librarians. The activities were selected partly because they appear to be measurable, and partly because a search of the literature suggested that previous investigators found academic librarians to be involved in these activities.

Five formal studies indicate how academic librarians are involved in professional development activities. One investigation, using a list of thirty-seven professional development activities, found a strong correlation between involvement and importance for reading professional literature in library science and subject specialty, attending library conventions and meetings, participating in library associations, recruiting for the profession, and visiting other libraries. ${ }^{8}$

A second study found that, while academic librarians were active in professional organizations, they were not too concerned with organizations not directly related to their profession. This study found a considerable amount of publishing activity among the participating librarians. ${ }^{9}$

A third survey of academic librarians reported that two-thirds of the respondents held memberships in professional library associations, but only two-fifths reported memberships in nonlibrary professional associations. Over two-fifths of the respondents had attended or participated in library workshops, short courses, or seminars in the previous two years. ${ }^{10}$

The selected professional development activities used in the present study were in- cluded as variables in a study designed to determine the relationship between a group of communication activities and a select group of professional situational characteristics of academic librarians. While the participants were involved in most of the activities, the findings seem to suggest that the publishing activities of the participants were slight. ${ }^{11}$

Participation in professional organizations and publication activity were two variables given special attention in a fifth study of seventy-seven academic librarians in middle management positions. The participants generally felt that attendance and participation in professional associations was unimportant, as were research and writing. Fortyeight percent of the participants indicated that they read between five and nine periodicals regularly. ${ }^{12}$ At least half had published books, monographs, articles, or reviews.

In summary, though there does not appear to be a strong consistency of involvement from study to study, the literature supports the contention that academic librarians are somewhat involved in the professional development activities selected for this study.

Ideally, a professional librarian would be defined as a person who has earned the master's degree in library science from an American Library Association-accredited library school. However, some colleges and universities have persons on their staffs designated as professional librarians by virtue of having earned a bachelor's degree in library science, or because they have gained many years of library and/or other experience that uniquely qualifies them for professional positions. A professional librarian is here defined as a person so designated by the directors of the libraries included in the the study.

No attempt is made to give a precise definition of collective bargaining. Rather, the emphasis is placed upon whether the librarians are included in a faculty bargaining unit that has been designated to represent them in discussions and negotiations with their institutions on economic and/or professional matters.

It is hypothesized that there is no significant difference between the professional development activities of academic librarians included in collective bargaining units and academic librarians not included in collective bargaining units. More specifically, the hy- 
pothesis is that between the two groups there is no significant difference in their involvement in the following professional development activities: (1) membership in professional library associations; (2) attendance at library association meetings at the state level or above; (3) membership in nonlibrary professional associations; (4) attendance at nonlibrary association meetings at the national level; (5) number of library journals read regularly; (6) number of nonlibrary professional journals read regularly; (7) attendance at workshops, short courses, or seminars (both library and nonlibrary); (8) number of visits to observe other libraries; (9) number of professional books read during the past year; (10) number of journal articles published during professional career; (11) number of papers in published proceedings during professional career; (12) number of articles or chapters in books published during professional career; (13) number of books written or edited during professional career; (14) number of journals edited during professional career.

The universe for the study includes the librarians of the public colleges and universities surveyed during the 1970-71 academic year by the United States Office of Education. ${ }^{13}$ The computer tape of the data, hereafter referred to as the $O E$ tape, collected during this survey contains information from 2,751 institutions or " $94 \%$ of the possible respondents to the survey." 14 Five hundred of the institutions were classifed as public fouryear colleges or as universities.

The May 15, 1972, issue of the Chronicle of Higher Education identified 254 colleges and universities with faculty collective bargaining agents -72 of which were public fouryear colleges and universities. ${ }^{15}$ This list was used as a basis for determining the population of academic librarians that are included in faculty collective bargaining units for the following reasons. First, a survey of the literature related to collective bargaining suggested that with few exceptions the librarians involved in collective bargaining were members of faculty bargaining units in their respective campuses. Second, no earlier statistics were found that were complete enough to provide a population of institutions with collective bargaining in which librarians were included. It was assumed that the librarians in the institutions on this list would have been involved with collective bargaining long enough for it to have had some effect on their activities. The librarians in these institutions constitute the collective bargaining population.

A careful check was made to identify campuses that had become involved in collective bargaining after the 1972 Chronicle listing but before the present study had begun. These institutions were omitted from the study. The librarians in the remaining 386 institutions constitute the population of librarians not included in a collective bargaining unit.

The colleges and universities in these two populations offer a variety of degreegranting programs ranging from the four-tofive-year bachelor's degree to a multitude of doctoral degree programs. In order to make more meaningful comparisons, the institutions were stratified into the following categories: university level, master's level, and baccalaureate level. This stratification process was made possible using various codes that are included on the OE tape. Baccalaureate level institutions were eliminated because it is assumed that the pressures for librarians to be involved in the professional development activities included as variables in this study are greater at the master's and university level institutions.

The sampling of the two populations was accomplished in two stages. First, using the $\mathrm{OE}$ tape, the number of librarians employed at each institution was determined. A random sample of libraries was selected until each level of each group contained 200 librarians.

In the second stage the directors of the randomly selected libraries were sent a brief questionnaire designed to determine the number of professional librarians on their staffs. In order to verify that each library had been placed in the correct group, the directors were asked if the librarians on their staffs were included in a faculty collective bargaining unit. Each director was also asked to provide this investigator with a directory of the professional librarians on their staffs. According to the $\mathrm{OE}$ tape, the selected libraries employed 853 professional librarians. The directors of these libraries indicated that at the time the study was being conducted, there were a total of 845 professional librarians in 
the thirty-eight libraries.

Data used to test the hypothesis was gathered using a questionnaire based on a survey instrument developed by Swisher. ${ }^{16}$ The findings reported here are based upon the responses of the 542 librarians who returned the questionnaire.

\section{Findings}

The first objective of the study was to determine the extent of involvement of the respondents in the selected professional development activities. Table 1 contains the mean scores for the professional development activities of the librarians in the noncollective and collective bargaining groups. ${ }^{17}$ In the noncollective bargaining group the three largest mean scores were for the number of library journals read during the previous year $\overline{(X}=$ 4.8908), number of professional books read during the previous year $\overline{(X}=4.8650)$, and the number of library association memberships $\overline{(X}=2.4412)$. Similarly, the three largest mean scores for the activities of the collective bargaining group were for the number of library journals read during the previous year $\overline{(X}=4.5428)$, number of professional books read during the previous year $\bar{X}=4.3725)$, and the number of library association memberships $\overline{(X}=2.4803)$. The pairs of mean scores for the number of library association meetings attended, number of nonlibrary professional association memberships, number of nonlibrary journals read during the previous year, the number of workshops attended, and the number of observation visits during the previous year indicate that the involvement of the respondents in publishing activities as compared with the other activities of the study was at a low level. Involvement in nonlibrary associations as members was also at a low level.

The second objective of the study was to determine if the involvement of the respondents in the selected group of professional development activities varied significantly between the collective bargaining and the noncollective bargaining groups. To test the hypothesis that there is no difference between the involvement of the librarians in the two groups in the professional development activities, the pairs of mean scores of the respondents' activities were compared for statistically significant differences at the .05 level using the student $t$ test. Table 1 notes the differences between each pair of mean scores and the corresponding $t$ value. No significant difference was found between the mean scores of the respondents in the two groups on any of the activities.

To offset the effect that employment in a university or master's level institution might have had on the involvement of the respon-

TABLE 1

Tests OF Significance of DifFerence betweEn the MEAN SCORES OF THE Professional DeVELopMEnt ACtivities OF THE ACADEMic Librarians in the NONCOlLECtive and the Collective Bargaining Groups

\begin{tabular}{lcccr}
\hline \hline & $\begin{array}{c}\bar{X} \\
\text { Noncollective } \\
\text { Bargaining } \\
\text { Group }\end{array}$ & $\begin{array}{c}\bar{X} \\
\text { Collective } \\
\text { Bargaining } \\
\text { Group }\end{array}$ & Difference & \multicolumn{1}{c}{$t$} \\
\hline Activity & 2.4412 & 2.4803 & 0.0391 & -0.32 \\
Library association membership & 1.7059 & 1.8947 & 0.1888 & -1.16 \\
Library association meetings & 0.9118 & 1.0197 & 0.1079 & -0.99 \\
Nonlibrary association memberships & 0.2143 & 0.2862 & 0.0719 & -0.72 \\
Nonlibrary association meetings & 4.8908 & 4.5428 & 0.3480 & 1.13 \\
Library journals read & 1.2143 & 1.0831 & 0.1312 & 0.71 \\
Nonlibrary journals read & 1.8655 & 2.1020 & 0.2365 & -1.42 \\
Workshops attended & 1.3445 & 1.6382 & 0.2937 & -1.78 \\
Observation visits & 4.8650 & 4.3725 & 0.4925 & 0.62 \\
Books read & 0.9496 & 1.2039 & 0.2543 & -0.83 \\
Journal articles published & 0.1471 & 0.1414 & 0.0057 & 0.09 \\
Papers published in proceedings & 0.1261 & 0.2401 & 0.1140 & -1.41 \\
Articles or chapters in books & 0.2437 & 0.2368 & 0.0069 & 0.07 \\
Author or editor of a book & 0.2269 & 0.1316 & 0.0953 & 0.70 \\
Editor of a journal & & & & \\
\hline
\end{tabular}


dents' in professional development activities, the $t$ test was applied to the mean scores of the librarians employed in the master's level institutions of both groups. The $t$ test was also applied to the mean scores of the librarians employed in the university level institutions in both groups. While no significant differences were found in the pairs of mean scores at the master's institutions level, two pairs of mean scores of the university level librarians were found to be significantly different: library association memberships and attendance at library association meetings (see tables 2 and 3$)$.

\section{Conclusions \\ AND IMPLICATIONS}

The data gathered in this study supported the overall hypothesis that there is no significant difference between the professional de-

TABLE 2

Tests of Significance of Difference betweEn the MeAN SCores of the Professional Development Activities OF THE ACADEMIC LiBRARIANS IN THE NONCOLLECTIVE and the Collective Bargaining Groups (University Level Respondents Only)

\begin{tabular}{lcccr}
\hline \hline & $\begin{array}{c}\bar{X} \\
\text { Noncollective } \\
\text { Bargaining } \\
\text { Group }\end{array}$ & $\begin{array}{c}\bar{X} \\
\text { Collective } \\
\text { Bargaining } \\
\text { Group }\end{array}$ & Difference & \multicolumn{1}{c}{ A } \\
Activity & 2.2033 & 2.5223 & 0.3190 & $-2.10^{*}$ \\
Library association membership & 1.6504 & 2.1401 & 0.4897 & $-2.10^{*}$ \\
Library association meetings & 1.0244 & 1.0382 & 0.0139 & -0.08 \\
Nonlibrary association memberships & 0.2764 & 0.2739 & 0.0025 & 0.02 \\
Nonlibrary association meetings & 4.2358 & 4.3376 & 0.1018 & -0.25 \\
Library journals read & 1.2358 & 1.0323 & 0.2035 & 0.95 \\
Nonlibrary journals read & 1.7642 & 2.0382 & 0.2740 & -1.27 \\
Workshops attended & 1.0813 & 1.4268 & 0.3455 & -1.69 \\
Observation visits & 5.5902 & 3.8431 & 1.7471 & 1.54 \\
Books read & 0.9431 & 1.2803 & 0.3372 & -0.99 \\
Journal articles published & 0.1138 & 0.1529 & 0.0391 & -0.53 \\
Papers published in proceedings & 0.0894 & 0.3057 & 0.2163 & -1.57 \\
Articles or chapters in books & 0.1870 & 0.2930 & 0.0106 & -0.90 \\
Author or editor of a book & 0.3496 & 0.1847 & 0.1649 & 0.63 \\
Editor of a journal & & & & \\
\hline
\end{tabular}

-Significant at the .05 level.

TABLE 3

TESTS OF Significance OF DifFerENCE BETWEEN THE MEAN Scores of the Professional Development Activities OF THE ACADEMIC LibRARIANS IN THE NONCOLLECTIVE AND the Collective Bargaining Groups (Master's Level Respondents Only)

\begin{tabular}{lcccr}
\hline \hline & $\begin{array}{c}\bar{X} \\
\text { Noncollective } \\
\text { Bargaining } \\
\text { Group }\end{array}$ & $\begin{array}{c}\bar{X} \\
\text { Collective } \\
\text { Bargaining } \\
\text { Group }\end{array}$ & Difference & \multicolumn{1}{c}{, } \\
\hline Activity & 2.6957 & 2.4354 & 0.2603 & 1.36 \\
Library association membership & 1.7652 & 1.6327 & 0.1325 & 0.59 \\
Library association meetings & 0.7913 & 1.0000 & 0.2087 & -1.53 \\
Nonlibrary association memberships & 0.1478 & 0.2993 & 0.1515 & -0.92 \\
Nonlibrary association meetings & 5.5913 & 4.7619 & 0.8294 & 1.77 \\
Library journals read & 1.1913 & 1.1370 & 0.0543 & 0.18 \\
Nonlibrary journals read & 1.9739 & 2.1701 & 0.1971 & -0.76 \\
Workshops attended & 1.6261 & 1.8639 & 0.2378 & -0.92 \\
Observation visits & 4.0957 & 4.9310 & 0.8353 & -0.76 \\
Books read & 0.9565 & 1.1224 & 0.1659 & -0.32 \\
Journal articles published & 0.1826 & 0.1293 & 0.0533 & 0.56 \\
Papers published in proceedings & 0.1652 & 0.1701 & 0.0049 & -0.06 \\
Articles or chapters in books & 0.3043 & 0.1769 & 0.1274 & 0.88 \\
Author or editor of books & 0.0957 & 0.0748 & 0.0209 & 0.51 \\
Editor of journals & & & & \\
\hline
\end{tabular}


velopment activities of the academic librarians in the collective bargaining group and the academic librarians in the noncollective bargaining group. However, when a distinction was made as to whether the respondents were employed in master's level institutions or university level institutions, the data showed that there were significant differences between the mean scores for the number of library association memberships held and for attendance at library association meetings of the respondents in the university level institutions. Since the pairs of mean scores for the other professional development activities were not significantly different, and since the pairs of mean scores of the professional development activities of the master's level institutions were also not significantly different, it may be that the differences found in the number of library association memberships held and the number of library association meetings attended (as was noted among the librarians employed in the university level institutions) were explainable by factors not considered in the present study. One factor (which was not explored) might be the geographical location of the respondents who participated in the study. For the most part, the librarians in the collective bargaining group were employed in institutions located in the northeastern part of the United States. Since the headquarters of the American Library Association is located east of the Mississippi River, and, since the annual conferences of this association tend to be held in cities east of the Mississippi River, librarians employed east of the Mississippi River may be more inclined to affiliate with the American Library Association and to attend its national conferences.

An examination of the publication activities of the respondents as suggested by the mean scores reported above leads to the conclusion that involvement in this type of activity by the librarians in both groups was at a low level.

The above findings appear to warrant the observation that, in general, employment in collective bargaining environments does not significantly affect the involvement of academic librarians in professional development activities. Thus, administrators and librarians alike should not assume that collective bargaining will enhance or impede professional development activities of academic librarians.

\section{REFERENCES}

1. Bernard Berelson, "Library Unionization," Library Quarterly 9:473-510 (Oct. 1939); John J. Clopine, “A History of Library Unions in the United States" (M.S.L.S. dissertation, Catholic Univ, of America, 1951); Eric J. Spicer, Trade Unions in Libraries: The Experience in the United States (Ann Arbor: Univ. of Michigan Pr., 1959); Melvin S. Goldstein, Collective Bargaining in the Field of Librarianship (New York: Pratt Institute, 1960).

2. Gail Schlachter, "Professional Librarians' Attitudes toward Professional Employee Associations as Revealed by Academic Librarians in Seven Midwestern States (V.I and II)" (Ph.D. dissertation, Univ. of Minnesota, 1971); James F. Wyatt, "A Study of the Attitudes of Academic Librarians, Library Directors and Academic Deans in Colleges and Universities of Eight Southern States toward Union Organizations and Collective Bargaining for Academic Librarians" (Ph.D. dissertation, Florida State Univ., 1974); Joseph A. Vignone, Collective Bargaining Procedures for Public Employees: An Inquiry into the Opinions and Attitudes of Public Librarians, Directors and
Board Members (Metuchen, N.J.: Scarecrow, 1971).

3. Theodore Lewis Guyton, Unionization: The Viewpoint of Librarians (Chicago: American Library Assn., 1975):

4. Gwendolyn Marie Stiggins Couzat, "Collective Bargaining in Academic Librarianship" (Ph.D. dissertation, Wayne State Univ., 1976).

5. Articles arguing against collective bargaining in libraries include: Keith Cottam, "Unionization for the Unhappy," Library Journal 92:510 (Feb. 1967); Keith Cottam, “Unionization Is Not Inevitable: A Plea for More Vigorous Professional Associations," Library Journal 93:4105-6 (Nov. 1, 1968); Lawrence J. Downey, "What Else Is There?" Focus on Indiana Libraries 23:110-11 (Sept. 1969). Articles arguing in favor of collective bargaining in libraries include: Eldred Smith, "Librarians and Unions: The Berkeley Experience," Library Journal 93:717-20 (Feb. 15, 1968); Fuad K. Suleiman and JoAnn D. Suleiman, "Collective Bargaining: Alternatives for Academic Librarians," Protean 2:26-31 (Summer 
1972); William T. Bulger, "Librarians and Collective Bargaining," Michigan Librarian 38:10-12 (Spring 1972); Charles J. Reiter, "Laying It on the Line," Library Journal 94:1953-54 (May 15, 1969).

6. Joseph W. Garbarino, Faculty Bargaining: Change and Conflict (New York: McGrawHill, 1975), p.57-59.

7. Elizabeth W. Stone, "A Study of Some Factors Related to the Professional Development of Librarians" (Ph.D. dissertation, American Univ., 1968), p.10.

8. Stone, "A Study of Some Factors," p.157.

9. Perry D. Morrison, The Career of the Academic Librarian: A Study of the Social Origins, Educational Attainments, Vocational Experience, and Personality Characteristics of a Group of American Academic Librarians (Chicago: American Library Assn., 1969).

10. Anita R. Schiller, Characteristics of Professional Personnel in College and University Libraries (Springfield, Ill.: Illinois State Library, 1969), p.53-54.

11. Robert Dean Swisher, "Professional Communication Behavior of Academic Librarians Holding Membership in the American Library Association" (Ph.D. dissertation, Indiana Univ., 1975).

12. Kenneth Plate, Management Personnel in Libraries: A Theoretical Model for Analysis (Rockaway, N.J.: American Faculty Pr., 1970).
13. Stanley V. Smith and Joel Williams, Library Statistics of College and Universities: Instructional Data, Part A, Fall 1971. Basic Information of Collections, Staff and Expenditures (Washington, D.C.: U.S. Department of Health, Education, and Welfare, Office of Education, 1972), p.3.

14. Allen Daniel Pratt, "A Logarithmic Measure of the Size of United States Academic Libraries" (Ph.D. dissertation, University of Pittsburgh, 1974), p.22. The author had access to the computer tape used to produce the printed report which was made available to Indiana University through a grant from the Council on Library Resources, Inc.

15. "Colleges and Universities Where Faculties Have Chosen Collective Bargaining Agents," The Chronicle of Higher Education 6, no.32:2 (May 15, 1972).

16. The questionnaire was based upon a survey instrument developed by Swisher, "Professional Communication Behavior of Academic Librarians."

17. For more detailed statistics and further analysis see the author's dissertation "A Study of the Relationship between Collective Bargaining Environments and the Professional Development Activities of Academic Librarians" (Ph.D. dissertation, Indiana Univ., 1980). 